\title{
Evolution of mammographic image quality in the state of Rio de Janeiro*
}

A evolução da qualidade da imagem em mamografia no Estado do Rio de Janeiro

\section{Vanessa Cristina Felippe Lopes Villar ${ }^{1}$, Marismary Horsth De Seta ${ }^{2}$, Carla Lourenço Tavares de Andrade ${ }^{2}$, Elizabete Vianna Delamarque ${ }^{3}$, Ana Cecília Pedrosa de Azevedo ${ }^{4}$}

Villar VCFL, De Seta MH, Andrade CLT, Delamarque EV, Azevedo ACP. Evolution of mammographic image quality in the state of Rio de Janeiro. Radiol Bras. $2015 \mathrm{Mar} / \mathrm{Abr} ; 48(2): 86-92$.

Abstract Objective: To evaluate the evolution of mammographic image quality in the state of Rio de Janeiro on the basis of parameters measured and analyzed during health surveillance inspections in the period from 2006 to 2011.

Materials and Methods: Descriptive study analyzing parameters connected with imaging quality of 52 mammography apparatuses inspected at least twice with a one-year interval.

Results: Amongst the 16 analyzed parameters, 7 presented more than $70 \%$ of conformity, namely: compression paddle pressure intensity (85.1\%), films development (72.7\%), film response (72.7\%), low contrast fine detail (92.2\%), tumor mass visualization (76.5\%), absence of image artifacts (94.1\%), mammography-specific developers availability (88.2\%). On the other hand, relevant parameters were below $50 \%$ conformity, namely: monthly image quality control testing $(28.8 \%)$ and high contrast details with respect to microcalcifications visualization (47.1\%).

Conclusion: The analysis revealed critical situations in terms of compliance with the health surveillance standards. Priority should be given to those mammography apparatuses that remained non-compliant at the second inspection performed within the one-year interval.

Keywords: Mammography; Breast neoplasms; Quality assurance; Health care; Quality control; Public health surveillance.

Resu mo Objetivo: Avaliar a evolução da qualidade da imagem de mamógrafos localizados no Estado do Rio de Janeiro, de 2006 a 2011 , com base em parâmetros medidos e observados durante inspeções sanitárias.

Materiais e Métodos: Estudo descritivo sobre a evolução de parâmetros que condicionam a qualidade da imagem focalizou 52 mamógrafos, inspecionados no mínimo duas vezes, com intervalo de um ano.

Resultados: Dos 16 parâmetros avaliados, 7 apresentaram mais de 70\% de conformidade: força do dispositivo de compressão (85,1\%), processamento dos filmes $(72,7 \%)$, resposta do filme do serviço $(72,7 \%)$, detalhes lineares de baixo contraste $(92,2 \%)$, visualização de massas tumorais (76,5\%), ausência de artefatos de imagem $(94,1 \%)$, existência de processadoras específicas para mamografia (88,2\%). Importantes parâmetros apresentaram-se abaixo de $50 \%$ de conformidade: realização de testes mensais da qualidade de imagem pelo estabelecimento $(28,8 \%)$ e detalhes de alto contraste, que dizem respeito à visualização de microcalcificações (47,1\%). Conclusão: A análise revelou situações críticas da atuação da vigilância sanitária, cuja prioridade deveria ser dirigida aos estacionários, ou seja, os mamógrafos que permaneceram na situação de não conformidade nas inspeções realizadas com intervalo de um ano.

Unitermos: Mamografia; Neoplasias da mama; Garantia da qualidade; Cuidados de saúde; Qualidade da imagem; Vigilância sanitária.

\section{INTRODUCTION}

Breast cancer represents a severe public health problem and, in Brazil, deficiencies in the diagnosis and treatment of this disease are pointed out, with huge disparities in outcomes resulting from disparities in geography, social, ethnic and

* Study developed at Escola Nacional de Saúde Pública Sergio Arouca/Fundação Oswaldo Cruz, Rio de Janeiro, RJ, Brazil.

1. Master, Health Management Analyst at Instituto Nacional de Infectologia Evandro Chagas/Fundação Oswaldo Cruz, Rio de Janeiro, RJ, Brazil.

2. PhDs, Professors, Public Health Post-Graduation Program, Escola Nacional de Saúde Pública Sergio Arouca/Fundação Oswaldo Cruz, Rio de Janeiro, RJ, Brazil.

3. Master, Research Assistant at Health Surveillance Collaboration Center - Escola Nacional de Saúde Pública Sergio Arouca/Fundação Oswaldo Cruz, Rio de Janeiro, RJ, Brazil.

4. PhD, Physicist, Rio de Janeiro State Heath Secretariat, Rio de Janeiro, RJ, Brazil. socio-economic aspects involved in mammography services rendering. Among the mentioned deficiencies, one highlights the delay in diagnosis resulting from failure in implementing an effective mammographic screening ${ }^{(1)}$, which is the modality of choice to detect even millimetric lesions.

Data of the Brazilian National Household Sampling Survey (Pesquisa Nacional por Amostra de Domicílio PNAD) reveal the increase in the number of mammographic procedures over the last years ${ }^{(2)}$, which corresponds to a general, yet uneven, increment in the access to mammography. Iniquities to be overcome apart, it is important to high-

Mailing Address: Vanessa Cristina Felippe Lopes Villar. Avenida Brasil, 4365, Manguinhos. Rio de Janeiro, RJ, Brazil, 21040-360. E-mail: vanessalopesvillar@ gmail.com.

Received June 2, 2014. Accepted after revision September 15, 2014. 
light that the effectiveness of such screening is influenced by parameters related to the mammography apparatus itself - compression force, compression paddle alignment, incidence of the $\mathrm{x}$-ray beam - and to the images processing, technique selection, patient positioning and images interpretation. All these parameters which affect the mammographic imaging quality should be in compliance with mammography standards in order to allow for a successful screening ${ }^{(3,4)}$.

Considering the academic and clinical consensus about mammography being the imaging method of choice for breast cancer screening ${ }^{(5)}$, it is expected that such a procedure produces good-quality images with the use of the lowest possible radiation dose. In Brazil, the initiatives aimed at mammography quality assurance started in 1991, with the Mammography Quality Control Program implemented by Colégio Brasileiro de Radiologia, whose adhesion was voluntary ${ }^{(6,7)}$. In the same decade, the Federal Ordinance 453/ 98 established the guidelines for protection in medical and odontological radiodiagnosis ${ }^{(6,8,9)}$.

Recently, several studies were developed about imaging quality ${ }^{(10,11)}$, recommendations for breast cancer screening $^{(12)}$, adherence to mammography ${ }^{(13)}$, new techniques related to breast cancer diagnosis ${ }^{(14-16)}$, as well as about the relevance of internal audits in mammography services as a tool to depict the service quality ${ }^{(17)}$.

Recognizing these and other initiatives undertaken by medical societies, health institutions, universities, research centers and government organs, the authors highlight the role played by the health surveillance services responsible for licensing and inspection of mammography centers. Further efforts should be made in the context of the implementation of the Programa Nacional de Qualidade em Mamografia (PNQM) - National Program of Quality in Mammography ${ }^{(18)}$, instituted by the Brazilian Ministry of Health in 2012. It is expected that the PNQM yields results similar to those achieved by the Mammography Quality Standards Act (MQSA), of 1992, in the United States of America ${ }^{(19)}$. For this purpose, it is necessary that the service has a quality program under the supervision of a physicist, including the capacitation of physicians and technicians involved in the operation of the service $\mathrm{e}^{(11,17)}$.

The present study was aimed at evaluating the evolution of the mammographic image quality with basis on the inspection of 52 apparatuses operating in the state of Rio de Janeiro in the period from 2006 to 2011 . It is important to observe that mammographic images quality - an issue that has already been resolved in developed countries -, has been a source of preoccupation in developing countries in the last decade $^{(3,19)}$. Thus, besides approaching the necessities in terms of improvement of the Brazilian health system, the present study may contribute to shed light on other realities where critical parameters regarding mammographic quality image are affecting the assistance quality, particularly as regards a timely diagnosis which is connected with the breast cancer treatment course and outcomes.

\section{MATERIALS AND METHODS}

The present study was approved by the Committee for Ethics in Research of Escola Nacional de Saúde Pública Sergio Arouca, under the number 151/2011 and did not require any external financial support.

The study is situated at the interface between the evaluation of the services quality and a normative evaluation, with a predominantly quantitative approach. The authors utilized secondary data collected from administrative records of the Health Surveillance Superintendence of the Health Secretariat of the State of Rio de Janeiro (Suvisa/SES/RJ) regarding inspections performed at mammography facilities. The data collected in the period between August and October/ 2011 represent numerical and categorical variables. The selected unit of analysis was the mammography apparatus. In cases of services with more than one apparatus, the authors have opted for keeping in the study the apparatus that had undergone two inspections in the period.

Inclusion criteria were the following: mammography apparatuses operating in centers under the responsibility of Suvisa/SES/RJ, inspected at least two times in the study period with a minimum one-year interval between inspections; availability of inspection reports in the local computer network. Mammography apparatuses whose inspection responsibility had been transferred to municipal instances prior to 2010 were excluded from the study. Once the inclusion and exclusion criteria were applied, 52 apparatuses operating in 52 services remained in the study.

A tool was constructed to collect the 16 study variables selected amongst the parameters included in the Suvisa/SES/ RJ Mammography Quality Inspection Schedule based on the Ordinance $453 / 98^{(8)}$, and on the measurements performed by the physicists of that health surveillance service. The description of those variables, as well as their performance expectations (standards), are shown on Table 1. The final results of the tests performed either directly in the apparatus or by means of a breast phantom were transformed into dichotomous variables in relation to compliance: compliant or non-compliant. Compliance corresponded to conformity with the parameters within the ranges recommended for each test included in the Suvisa/SES/RJ inspection schedule.

A descriptive analysis of the conformity with parameters at the first and second inspections was performed with the aid of the Statistical Package for the Social Science (SPSS ${ }^{\circledR}$ version 17). For The compliance situations in the first and second inspections were compared for the whole set of apparatuses, resulting in a parameter evolution analysis classified according to Table 2 contents.

\section{RESULTS}

The set o facilities included in the present study were constituted as follows: $21(40.4 \%)$ mammography apparatuses operating in hospitals, and $31(59.6 \%)$ operating in outpatient units. As regards legal nature, 9 services $(17.3 \%)$ are public; $35(67.3 \%)$ private, $7(13.46 \%)$ beneficent enti- 
Table 1-Parameters and standards utilized in the study.

\begin{tabular}{|c|c|}
\hline Parameters & Standards \\
\hline Monthly image quality testing & $\begin{array}{l}\text { The facility performs monthly imaging quality testing and the results remain at the health surveillance } \\
\text { disposal }\end{array}$ \\
\hline Collimation evaluation & The $x$-rays must cover the whole film surface, without exceeding the compression paddle borders \\
\hline Automatic exposure control & $\begin{array}{l}\text { Variations should not be }>20 \% \text { for breasts between } 2 \text { and } 5 \mathrm{~cm} \text { in thickness. It is desirable that the } \\
\text { variation does not exceed } 10 \%\end{array}$ \\
\hline Compression paddle force & The compression paddle force should be between 11 and $18 \mathrm{~kg}$ \\
\hline Compression paddle alignment & The maximum acceptable deformation is $5 \mathrm{~mm}$ \\
\hline Surface entrance dose in the phantom & The dose should be $<10$ mGy \\
\hline Films processing & Films processing must comply with the physical quality standards \\
\hline Films response & The films must comply with minimum specifications for appropriate images generation \\
\hline High-contrast details (microcalcifications) & Small-sized objects should be visualized up to sets with $0.25 \mathrm{~mm}$ in diameter \\
\hline Low-contrast circular details (disks) & $\begin{array}{l}\text { Low-contrast objects, polyester disks with } 2 \mathrm{~mm} \text { in diameter and thickness between } 0.5 \text { and } 3.0 \mathrm{~mm} \\
\text { should be visualized up to the } 7 \text { th disk }\end{array}$ \\
\hline Low-contrast linear details (fibers) & $\begin{array}{l}\text { Low-contrast linear objects of different diameters mimic fibrotic tissue into fat tissue and should be } \\
\text { visualized up to } 0.75 \mathrm{~mm} \text { fiber }\end{array}$ \\
\hline Visualization of tumor masses & $\begin{array}{l}\text { Nylon spherical caps mimic tumor masses and should be visualized up to the } 4 \text { th cap of } 4.0 \mathrm{~mm} \text { in } \\
\text { diameter and } 2.0 \mathrm{~mm} \text { thickness }\end{array}$ \\
\hline Background optical density (OD) & $\begin{array}{l}\text { Measurement at a spot on the phantom image located at } 6 \mathrm{~cm} \text { from the chest wall and laterally centered } \\
\text { on the film. Threshold between } 1.10 \text { and } 1.80\end{array}$ \\
\hline Contrast index & $\begin{array}{l}\text { The image contrast affects the visualization of structures. Represented by optical density points on the film } \\
\text { of the evaluated facility. Values between } 0.55 \text { and } 0.67\end{array}$ \\
\hline Absence of imaging artifacts & $\begin{array}{l}\text { Imaging artifacts are defects in the image processing which may result either in loss or marking of } \\
\text { information. They should not be present }\end{array}$ \\
\hline $\begin{array}{l}\text { Availability of mammography-specific film proces- } \\
\text { sor }\end{array}$ & $\begin{array}{l}\text { The availability of mammography-specific film processor ensures the maintenance of proper adjustment to } \\
\text { the thickness of the mammographic film }\end{array}$ \\
\hline
\end{tabular}

Table 2-Criteria for parameters evolution analysis.

\begin{tabular}{ll}
\hline Status & \multicolumn{1}{c}{ Description } \\
\hline Compliance stability & $\begin{array}{l}\text { The compliance observed at the first inspec- } \\
\text { tion remained unchanged at the second in- } \\
\text { spection } \\
\text { The compliance observed at the first inspec- } \\
\text { tion was no longer observed at the second } \\
\text { inspection }\end{array}$ \\
$\begin{array}{l}\text { The non-compliance observed at the first } \\
\text { inspection evolved to a compliance situation } \\
\text { at the second inspection }\end{array}$ \\
$\begin{array}{l}\text { The non-compliance observed at the first } \\
\text { inspection remained unchanged at the sec- } \\
\text { ond inspection }\end{array}$ \\
\hline
\end{tabular}

ties; and one (1.9\%) military entity. Twenty-eight $(53.8 \%)$ services provide health care through the Unified Health System, and $24(46.2 \%)$ do not.

As the 16 evaluated parameters are considered, the mammography apparatuses presented more than $70 \%$ compliance with 7 of those parameters, namely: compression paddle force; films processing; film response; low-contrast linear detail (fibers); tumor mass visualization; absence of imaging artifacts; availability of mammography-specific film processors. For three parameters, the compliance was below 50\%: monthly imaging quality testing; high-contrast detail (microcalcifications); low-contrast circular details (fibers). The worst result was observed for monthly imaging quality testing, with very low values $-26.9 \%$ at the first inspection and $28.8 \%$ at the second inspection. Table 3 shows the rates
Table 3-Percentage of mammography apparatuses in compliance situation at the first and second inspections.

\begin{tabular}{lcc}
\hline & \multicolumn{2}{c}{ Compliance (\%) } \\
\cline { 2 - 3 } Parameters & $\begin{array}{c}\text { First } \\
\text { inspection }\end{array}$ & $\begin{array}{c}\text { Second } \\
\text { inspection }\end{array}$ \\
\hline Monthly image quality testing & 26.9 & 28.8 \\
Collimation evaluation & 64.6 & 62.5 \\
Automatic exposure control & 68 & 58 \\
Compression paddle force & 72.3 & 85.1 \\
Compression paddle alignment & 52.9 & 52.9 \\
Entrance dose on the phantom surface & 73.1 & 51.9 \\
Films processing & 54.5 & 72.7 \\
Facility film response & 47.7 & 72.7 \\
High-contrast details (microcalcifications) & 80.4 & 47.1 \\
Low-contrast circular details (disks) & 47.1 & 45.1 \\
Low-contrast linear details (fibers) & 96.1 & 92.2 \\
Tumor masses visualization & 60.8 & 76.5 \\
Background optical density & 68.6 & 62.7 \\
Contrast index & 66.0 & 64.0 \\
Absence of imaging artifacts & 64.7 & 94.1 \\
Availability of mammography-specific film pro- & 88.5 & 88.2 \\
cessors & & \\
\hline
\end{tabular}

of conformity regarding each parameter for the whole set of apparatuses.

The comparative analysis of the compliance situation evolution is presented according to the possible situations, namely, compliance stability, compliance rate increase or decrease, and stationary. 
The evolution of parameters for mammography apparatuses and processors is shown on Table 4. Compression paddle force and films processing are highlighted. The first one remained in a satisfactory situation - compliance stability at both inspections - added of improvement in compliance situation for $15.4 \%$ of the apparatuses. Even remaining in a less advantaged compliance situation (stable compliance at $26.9 \%$ ), the second parameter demonstrated improvement for other $32.7 \%$ of the total of mammography apparatuses.

The evolution of the quality of the image itself, i.e., as a result of the mammographic study performed, is shown on Table 5. On this table, the best performance is that of absence of imaging artifacts, considering the stable conformity situation at $59.6 \%$ of the apparatuses, and the improvement in the compliance situation for other $30.8 \%$. In this parameter, decrease in compliance rates and stationary situation present with low percentages, $3.8 \%$.

For the majority of parameters, however, the improvement in compliance at the second inspection was not so significant and the high rate of stationary situation, i.e. non compliance at both inspections, is worrisome.

\section{DISCUSSION}

Image quality can be understood as a mammographic image whose optical density is agreeable to the human eye, allowing for a good visualization of tissues relevant for a reliable diagnosis ${ }^{(20)}$, influenced by factors such as breasts density, radiographic technique, lesion site, malignancy characteristics and radiologist's tiredness ${ }^{(5)}$. The quality in the image is associated with the interpretation that is subjective and is connected with the observer's experience, physical tiredness and effort, and visibility conditions ${ }^{(20)}$.

Although each health system undertakes initiatives compatible with their operational conditions, the improvement in mammographic image quality has been internationally attributed to the development of accreditation and certification programs besides state-level regulations in this field ${ }^{(21)}$.

In the United States of America, as a recognition of the necessity of a countrywide regulation on mammography, a set of recommendations was implemented by means of the passing of the MQSA in $1992^{(22)}$.

A study reports an improvement in the quality of mammography in the United States as a result of accreditation and of the MQSA, which has contributed to the early detection of breast cancer and consequential increase in the patient's survival $^{(22)}$. However, in North Carolina, the gain in mammography quality is not formally attributed only to the MQSA. The authors point out that this gain in quality started with the ACR - Mammography Accreditation Program and the previously performed inspections ${ }^{(23)}$.

Table 4-Evolution of parameters related to mammography apparatuses and film processors.

\begin{tabular}{|c|c|c|c|c|c|c|c|c|c|c|}
\hline \multirow[b]{2}{*}{ Parameters } & \multicolumn{8}{|c|}{ Status } & & \\
\hline & $n$ & $\%$ & $n$ & $\%$ & $n$ & $\%$ & $n$ & $\%$ & $n$ & $\%$ \\
\hline Collimation evaluation & 17 & 32.7 & 13 & 25 & 12 & 23.1 & 6 & 11.5 & 48 & $92.3^{*}$ \\
\hline Automatic exposure control & 25 & 48.1 & 9 & 17.3 & 4 & 7.7 & 12 & 23.1 & 50 & $96.2^{*}$ \\
\hline Compression paddle force & 29 & 55.8 & 5 & 9.6 & 8 & 15.4 & 5 & 9.6 & 47 & $90.4^{*}$ \\
\hline Entrance dose on the phantom surface & 20 & 38.5 & 18 & 34.6 & 7 & 13.5 & 7 & 13.5 & 52 & 100 \\
\hline Films processing & 14 & 26.9 & 8 & 15.4 & 17 & 32.7 & 5 & 9.6 & 44 & $84.6^{*}$ \\
\hline Facility film response & 13 & 25 & 5 & 9.6 & 19 & 36.5 & 7 & 13.5 & 44 & $84.6^{*}$ \\
\hline Mammography-specific film processors & 36 & 69.2 & 3 & 5.8 & 3 & 5.8 & 3 & 5.8 & 52 & 100 \\
\hline
\end{tabular}

* The difference for $100 \%$ corresponds to the absence of data in the inspection reports.

Table 5-Evolution of parameters related to imaging quality.

\begin{tabular}{|c|c|c|c|c|c|c|c|c|c|c|}
\hline \multirow[b]{2}{*}{ Parameters } & \multicolumn{8}{|c|}{ Status } & & \\
\hline & $n$ & $\%$ & $n$ & $\%$ & $n$ & $\%$ & $n$ & $\%$ & $n$ & $\%$ \\
\hline Monthly imaging quality testing & 8 & 15.4 & 5 & 10.0 & 7 & 13.5 & 29 & 56 & 49 & $94.2^{*}$ \\
\hline High-contrast details (microcalcifications) & 22 & 42.3 & 18 & 34.6 & 2 & 3.8 & 9 & 17.3 & 51 & $98.1^{*}$ \\
\hline Low-contrast circular details (disks) & 12 & 23.1 & 12 & 23.1 & 11 & 21.2 & 16 & 30.8 & 51 & $98.1^{*}$ \\
\hline Tumor masses visualization & 28 & 53.8 & 3 & 5.8 & 12 & 23.1 & 8 & 15.4 & 51 & $98.1 *$ \\
\hline Background optical density & 23 & 44.2 & 11 & 21.2 & 9 & 17.3 & 8 & 15.4 & 51 & $98.1^{*}$ \\
\hline Contrast index & 22 & 42.3 & 11 & 21.2 & 10 & 19.2 & 7 & 13.5 & 50 & $96.2^{*}$ \\
\hline Absence of imaging artifacts & 31 & 59.6 & 2 & 3.8 & 16 & 30.8 & 2 & 3.8 & 51 & $98.1^{*}$ \\
\hline
\end{tabular}

* The difference for $100 \%$ corresponds to the absence of data in the inspection reports. 
In Europe, the European Guidelines ${ }^{(24)}$ (2006) include the directives for the several facilities specialized in breast cancer treatment. Such guidelines have responded to the need for standardization of the measures to fight against breast cancer in all the European countries. The regulations cover from implementation of screening programs to treatment, including quality assurance measures ${ }^{(24)}$.

In a less comprehensive way, Turkey, where no quality standard for accreditation is established, has a Handbook of Quality Standards for Conventional Mammography issued by the local radiological society. In Istanbul, a study involving 50 public and private facilities concluded that the mammography quality was insufficient in 19 (38\%) out of the 50 facilities $^{(25)}$.

In Brazil, following this international trend, there was already a previous, pioneering initiative by Colégio Brasileiro de Radiologia, in 1991, with the Programa de Controle de Qualidade em Mamografia Program of Quality Control in Mammography), and later with the Federal ordinance 453/ $98^{(6-8)}$. However, despite the nationwide reach of such an Ordinance, one has not observed a standardization of those initiatives in the different Brazilian states and cities. Besides the recent contribution of professionals affiliated to medical societies or working in health institutions, universities and research centers ${ }^{(5,10-17,26)}$, some studies attribute the improvements to the regulatory activity of the health surveillance $\operatorname{agency}^{(6,9,27)}$.

Beside the international initiatives, Brazilian studies approach data regarding the imaging quality ${ }^{(9,27)}$. Although not likely to generalization, the results observed in Rio de Janeiro may demonstrate that the reality found in this state is quite similar to the one observed in most Brazilian states, considering the nationwide nature of the regulations and that all the health surveillance departments at state levels are subjected to the same operational conditions.

Despite methodological differences, one can affirm the present results are different from the ones reported by another study developed in the Paraíba state approaching the evolution of imaging quality in 17 facilities in the period from 1999 to $2003^{(9)}$. Such study concluded that there was a positive impact of the quality program implementation on the mammography images quality. Five facilities achieved a range corresponding to excellence level, other five facilities achieved a level rated as desirable, and seven achieved the minimum desirable level. None of the facilities was below the minimum desirable level, i.e. non-compliance with at least four evaluated parameters ${ }^{(9)}$.

On the other hand, a study developed in the Federal District in 2008, reported a positive, but below the expected ( $90 \%$ compliance), impact of the health surveillance intervention on mammography services quality ${ }^{(27)}$. In a second study evaluating 35 facilities in the same location in 2012, the implementation of a mammography quality program was effective in improving the parameters of mammography apparatuses operation in spite of the fact that $40 \%$ of the facilities did not achieved the acceptable level of $70 \%$ compliance $^{(6)}$.

In the present study developed in Rio de Janeiro, positive results were observed in relation to compression paddle force between 11 and $18 \mathrm{~kg}(72.3 \%$ at the first inspection to $85.1 \%$ at the second). A positive result was also observed in the Federal District ${ }^{(6)}$, with $48.6 \%$ at the first inspection and $77.1 \%$ at the second. The relevance of this parameter is related to the appropriate compression of the breast, separating the tissue components in order to avoid images overlapping and loss of definition of the breast structures, at the same time reducing the absorbed radiation dose to the breast and improving lesions visibility with compression tolerable by the patient (between 11 and $18 \mathrm{~kg})^{(8,9)}$.

The relevance of the automatic exposure control consists in maintaining a certain constant degree of darkening of breast images with thicknesses between 2 and $5 \mathrm{~cm}$. In such study, the level of compliance in relation the parameter "automatic exposure control" decreased from $68.0 \%$ to $58.0 \%$, which is worrisome. Such a fact was not observed in the study of the Federal District, which reported an increase from $37.1 \%$ to $68.6 \%{ }^{(6)}$. Automatic exposure control is the most important procedure directly related to radiation dose and imaging quality, and the emphasis on the automatic exposure control testing may provide information on the system performance $^{(21)}$.

As regards the radiographic films processing, the results of compliance observed at the second inspection in the state of Rio de Janeiro $(72.7 \%)$ are above those found in the Federal District $(45.7 \%)^{(6)}$, but one observes that films processing still remains as a critical issue in the mammographic images production chain. This is confirmed by the visualization of low-contrast circular images (disks). According to Corrêa et al. ${ }^{(27)}$, the visualization of low-contrast circular details is the most reliable image quality indicator reflecting the image processing quality. In Rio de Janeiro, there was a decrease in compliance to a level $<50 \%$, from $47.1 \%$ to $45.1 \%$. This was also observed in the Federal District, with $62.9 \%$ at the first inspection to $48.6 \%$ at the second ${ }^{(6)}$.

In the present study, the results that approach most nearly those reported by previous studies are related to the parameter "visualization of low-contrast linear details" (fibers) of several diameters simulating fibrotic tissues extension into fat tissue and tumor masses ${ }^{(28)}$. The studies developed in the Federal District report almost $100 \%$ compliance $^{(6)}$ as compared with $96.1 \%$ and $92.2 \%$ in Rio de Janeiro. For the parameter "tumor masses visualization", this result is particularly promising, even without achieving the expected level of compliance. Among all the image quality parameters, this one corresponds to a realistic measurement of image quality $^{(28)}$.

Another important parameter is "absence of imaging artifacts”. Artifacts are defects generally resulting from inappropriate films handling ${ }^{(28)}$, which may affect the final imaging results and mask or hide possible abnormalities ${ }^{(20)}$. 
In Rio de Janeiro, the compliance with the parameter "absence of imaging artifacts" increase from $64.7 \%$ to $94.1 \%$, as compared with $40 \%$ and $68.6 \%$ in the Federal District.

The dissociation between the requirement of monthly film processing quality control testing and mandatory availability of such testing equipment ${ }^{(8,9)}$ has been pointed out as a key issue. It is important to highlight that it is a responsibility of the facility to perform such testing. This parameter presented the worst results, with $56.0 \%$ of apparatuses in stationary situation.

The Ordinance $453 / 98^{(8)}$ establishes that an imaging quality evaluation be monthly performed with a phantom, with recording and filing of such images for inspection by the health surveillance authority; and that the testing be performed by a physicist specialized in physics of radiodiagnosis ${ }^{(8)}$. According to several facilities, particularly those located away from the state-metro region, this represents a difficulty, but this does not exempt them to offer good-quality mammography services, as professional resources can be shared by different facilities.

The implementation of a mammography quality control program should include human resources training and capacitation as a key factor to strengthen and improve the program outcomes ${ }^{(3,7)}$.

Despite the increased mammography coverage ${ }^{(2)}$, the present study demonstrated that data for the state of Rio de Janeiro indicate that the improvement in the access to the method was not followed by the required improvement in the imaging quality. Although the study is restricted to mammography apparatuses inspected by Suvisa/SES/RJ, it is estimated that such apparatuses present with performance similar to the ones operating in other regions of the country even considering the inequalities in the distribution of goods and services -, considering that they are subjected to the same technical standards and involved in a single technological and regulatory context.

The wealth of collected data indicates the necessity of further studies and also the strengthening of the Division of Radioprotection and Mammography at Suvisa/SES/RJ, particularly after the implementation of the Programa Nacional do Controle do Câncer de Mama (National Breast Cancer Management Program $)^{(18)}$, considering the relevance of the partnerships with health surveillance agencies for consolidating the measures aimed at radiation dose control, imaging quality control, and image interpretation.

The compliance evolution analysis revealed critical situations requiring emphasis on the health surveillance actions within a context of scarce resources. In the impossibility of inspecting all the mammography apparatuses, priority should be given to the ones in stationary situation and to those that remained in non-compliance situation at inspections performed with a minimum one-year interval.

The PNQM ${ }^{(18)}$ reflects the necessity of standardization and monitoring of mammography at a nationwide level, and indicates the course of action for the next years with the purpose of improving the quality of mammography studies offered to the population, an action where the health surveillance plays a fundamental role in conjunction with other agencies and societies in the healthcare sphere ${ }^{(18)}$. Thus, these initiatives are similar to those undertaken by other foreign programs such as the MQSA (United States of America) ${ }^{(19)}$ and the European Guidelines ${ }^{(24,29)}$.

\section{Acknowledgements}

To Superintendência de Vigilância Sanitária (Health Surveillance Superintendency) - Secretaria de Estado de Saúde do Rio de Janeiro (Health Secretariat of Rio de Janeiro State) (Suvisa/SES/RJ).

\section{REFERENCES}

1. Lee BL, Liedke PE, Barrios CH, et al. Breast cancer in Brazil: present status and future goals. Lancet Oncol. 2012;13:e95-e102.

2. Brasil. Instituto Brasileiro de Geografia e Estatística. Pesquisa nacional por amostra de domicílios 2008 - suplemento. Um panorama da saúde no Brasil - Acesso e utilização dos serviços, condições de saúde e fatores de risco e proteção à saúde 2008 [Internet]. [acessado em 27 de março de 2011]. Disponível em: http://www.ibge.gov.br/ home/estatistica/populacao/panorama_saude_brasil_2003_2008/ default.shtm .

3. Pires SR, Medeiros RB, Schiabel H. Banco de imagens mamográficas para treinamento na interpretação de imagens digitais. Radiol Bras. 2004;37:239-44.

4. Knox S. The European advocacy perspective on mammography screening. Breast. 2011;20:93-5.

5. Calas MJG, Gutfilen B, Pereira WCA. CAD e mamografia: por que usar esta ferramenta? Radiol Bras. 2012;45:46-52.

6. Corrêa RS, Freitas-Junior R, Peixoto JE, et al. Efetividade de programa de controle de qualidade em mamografia para o Sistema Único de Saúde. Rev Saúde Pública. 2012;46:769-76.

7. Koch H, Castro MVK. Qualidade da interpretação do diagnóstico mamográfico. Radiol Bras. 2010;43:97-101.

8. Brasil. Ministério da Saúde. Portaria MS/SVS no 453 , de $1^{\circ}$ de junho de 1998. Aprova o regulamento técnico que estabelece as diretrizes básicas de proteção radiológica em radiodiagnóstico médico e odontológico, dispõe sobre o uso dos raios $\mathrm{X}$ diagnósticos em todo território nacional e dá outras providências. Brasília, DF: Diário Oficial da União, 2 de junho de 1998.

9. Ramos MMB, Dimenstein R, Lederman HM. Impacto das ações de vigilância sanitária no programa de controle de qualidade dos serviços de mamografia no Estado da Paraíba, no período de 1999 a 2003. Radiol Bras. 2010;43:319-23.

10. Rodrigues DCN, Freitas-Junior R, Corrêa RS, et al. Performance of diagnostic centers in the classification of opportunistic screening mammograms from the Brazilian public health system (SUS). Radiol Bras. 2013;46:149-55.

11. Goto RE, Pires SR, Medeiros RB. Identificação de parâmetros de qualidade de impressão para a garantia da detecção de estruturas presentes na mamografia digital. Radiol Bras. 2013;46:156-62.

12. Urban LABD, Schaefer MB, Duarte DL, et al. Recomendações do Colégio Brasileiro de Radiologia e Diagnóstico por Imagem, da Sociedade Brasileira de Mastologia e da Federação Brasileira das Associações de Ginecologia e Obstetrícia para rastreamento do câncer de mama por métodos de imagem. Radiol Bras. 2012;45:334-9.

13. Azevedo AC, Canella EO, Djahjah MCR, et al. Conduta das funcionárias de um hospital na adesão ao programa de prevenção do câncer de mama. Radiol Bras. 2012;45:215-8.

14. Barra FR, Barra RR, Barra Sobrinho A. Novos métodos funcionais na avaliação de lesões mamárias. Radiol Bras. 2012;45:340-4. 
15. Pardal RC, Abrantes AFL, Ribeiro LPV, et al. Rastreio de lesões mamárias: estudo comparativo entre a mamografia, ultrassonografia modo-B, elastografia e resultado histológico. Radiol Bras. 2013; 46:214-20.

16. Bitencourt AGV, Lima ENP, Chojniak R, et al. Correlação entre resultado do PET/CT e achados histológicos e imuno-histoquímicos em carcinomas mamários. Radiol Bras. 2014;47:67-73.

17. Badan GM, Roveda Júnior D, Ferreira CAP, et al. Auditoria interna completa do serviço de mamografia em uma instituição de referência em imaginologia mamária. Radiol Bras. 2014;47:74-8.

18. Instituto Nacional de Câncer José Alencar Gomes da Silva. Controle do câncer de mama. [acessado em $1^{\circ}$ de setembro de 2014]. Disponível em: http:/www2.inca.gov.br/wps/wcm/connect/acoes_ programas/site/home/nobrasil/programa_controle_cancer_mama/ controle_garantia_qualidade_mamografia .

19. U.S. Food and Drug Administration. Mammography Quality Standards Act and Program. [acessado em 9 de março de 2011]. Disponível em: www.fda.gov/Radiation-EmittingProducts/ MammographyQualityStandardsActandProgram/default/htm.

20. Pina DR, Morceli J, Duarte SB, et al. Otimização de imagens mamográficas. Radiol Bras. 2006;39:351-4.

21. Reis C, Pascoal A, Sakellaris T, et al. Quality assurance and quality control in mammography: a review of available guidance worldwide. Insights Imaging. 2013;4:539-53.
22. Destouet JM, Bassett LW, Yaffe MJ, et al. The ACR's Mammography Accreditation Program: ten years of experience since MQSA. J Am Coll Radiol. 2005;2:585-94.

23. Pisano ED, Schell M, Rollins J, et al. Has the mammography quality standards act affected the mammography quality in North Carolina? AJR Am J Roentgenol. 2000;174:1089-91.

24. Perry N, Broeders M, de Wolf C, et al. European guidelines for quality assurance in breast cancer screening and diagnosis. Fourth edition - summary document. Ann Oncol. 2008;19:614-22.

25. Gürdemir B, Aribal E. Assessment of a mammography quality in Istanbul. Diagn Interv Radiol. 2012;18:468-72.

26. Koch H. Auditoria em serviço de diagnóstico por imagem da mama. Radiol Bras. 2014;47(2):v.

27. Corrêa RS, Peixoto JE, Silver LD, et al. Impacto de um programa de avaliação da qualidade da imagem nos serviços de mamografia do Distrito Federal. Radiol Bras. 2008;14:109-14.

28. Brasil. Ministério da Saúde. Instituto Nacional de Câncer Mamografia: da prática ao controle. Ministério da Saúde. Instituto Nacional de Câncer. Rio de Janeiro: INCA; 2007.

29. Arbyn M, Van Oyen H, Lynge E, et al. European Commission's proposal for a council recommendation on cancer screening. BMJ. 2003;327:289-90. 